\title{
The success of multi-sector participation in the management of revenue for beneficiary communities of South African renewable energy companies - sub-model A
}

\author{
Ric Amansure, Chris Adendorff* \\ Nelson Mandela Metropolitan University, Department of Developmental Studies, PO Box 77000, \\ Port Elizabeth 6031, South Africa
}

\begin{abstract}
Multi-sector participation is one of three sub-models that resulted from the splitting of the original model that resulted from the data analysis as part of a thesis entitled 'A theoretical for successful management of revenue for beneficiary communities of renewable energy companies in South Africa.' The submodel provides specific guidance for the multi-sector participation of enterprises, stakeholders, industry experts and community development practitioners in the renewable energy sector to create a proactive, effective, and relevant decision-making process for achieving success in the management of revenue for beneficiary communities. To address the primary objective, a number of secondary objectives were formulated through the development of a conceptual model consisting of identified variables based on a comprehensive survey of the related literature. By constructing a path diagram between the independent variable and subsequent intervening and dependent variables, appropriate hypotheses were developed. Primary data sourced from an identified national and international population of community management practitioners
\end{abstract}

were collected using an electronic measuring instrument. These data were analysed and tested empirically using structural equation modelling. The determinants that were identified through a review of the literature as elements of multi-sector participation that influences the success of revenue management for beneficiary communities for South African renewable energy companies included the use of outside advice, financial management, support services, and good governance.

Keywords: renewable energy, green energy, beneficiary communities, community development, revenue management, socio-economic development, economic development, multi-sector participation

Journal of Energy in Southern Africa 28(1): 63-75

DOI: http://dx.doi.org/10.17159/2413-3051/2017/v28i1a1418

Published by the Energy Research Centre, University of Cape Town ISSN: 2413-3051 http://journals.assaf.org.za/jesa

Sponsored by the Department of Science and Technology

\footnotetext{
* Corresponding author. Tel: +27 (0)83 651 6789:

email: cadendorff@nmmu.ac.za
} 


\section{Introduction}

The 'Sustainable energy for all' initiative was launched by Mr Ban Ki-moon, then SecretaryGeneral of the United Nations Organisation, in September 2011 (REN21, 2014). It signalled a new approach of creating solutions on the ground, in a bottom-up manner, where implementation does not have to wait forever for political unanimity in a world where many other priorities are erroneously made to appear to be more urgent and pressing (SAWEA, 2014). The renewable energy sector is one of the fastest growing new industries in the Republic of South Africa (RSA). The Bloomberg New Energy Finance Climate Scope Report recently ranked RSA third behind China and Brazil globally, and first among African countries, for clean energy investment (Glickman, 2014). However, socio-economic and enterprise development as one of the main benefits to be derived from the industry is not achieving successful management of revenue for beneficiary communities in the renewable energy sector in RSA. Beneficiary communities refer to those communities that must receive socio-economic development benefits from the renewable energy companies located in the area surrounding the renewable energy farm. Challenges in good governance and long-term planning are causing significant harm to communities that are already vulnerable, and threaten to negatively affect the industry's ability to fulfil its obligation to alleviate, transform and ultimately eradicate poverty in some of the poorest communities. Currently, there is little public discourse about how the accrued revenue will affect beneficiary communities or how the revenue will be managed over the next twenty years towards 2035 .

This investigation focuses on the first sub-model of a comprehensive model to explain multi-sector participation in the perceived success of the man- agement of revenue for beneficiary communities. The comprehensive model consists of three submodels (in effect three sets of independent variables), namely: multi-sector participation (addressed in this paper), transformational change, and sustainable initiatives (Amansure, 2016). Owing to the limited sample size, the entire matrix of responses in this study could not be subjected to single exploratory factor analysis and, consequently, the model was split into the three sub-models.

\section{Sub-model A: Multi-sector participation (See Figure 1)}

The independent variables associated with this submodel - including distinctive benefits, support services, outside advice, financial management, and the intervening variable of good governance - suggest multi-sector participation in the management of revenue for beneficiary communities. Multi-sector refers to the involvement of government, the private sector and civil society. Participation refers to taking advantage of knowledge and skills, accessing expertise, forming partnerships and accessing resources. In multi-sector participation, the concept of ubuntu, expressed as 'I am because of others', is deliberately and actively applied. It must be noted that financial management and good governance are key components of this sub-model. In the literature review, the researcher investigated the link between corporate social responsibility and revenue management and confirmed the importance of multi-sector participation as a key component successful management of revenue for beneficiary communities. The sigma management model refers to a multi-stakeholder project to provide practical, yet comprehensive, guidance to organisations wanting to improve their sustainability, and CSR management and performance (Jonker \& De Witte,

\section{\begin{tabular}{|l|l|l|}
\hline INDEPENDENT VARIABLES & INTERVENING VARIABLE & DEPENDENT VARIABLE \\
\hline
\end{tabular}}

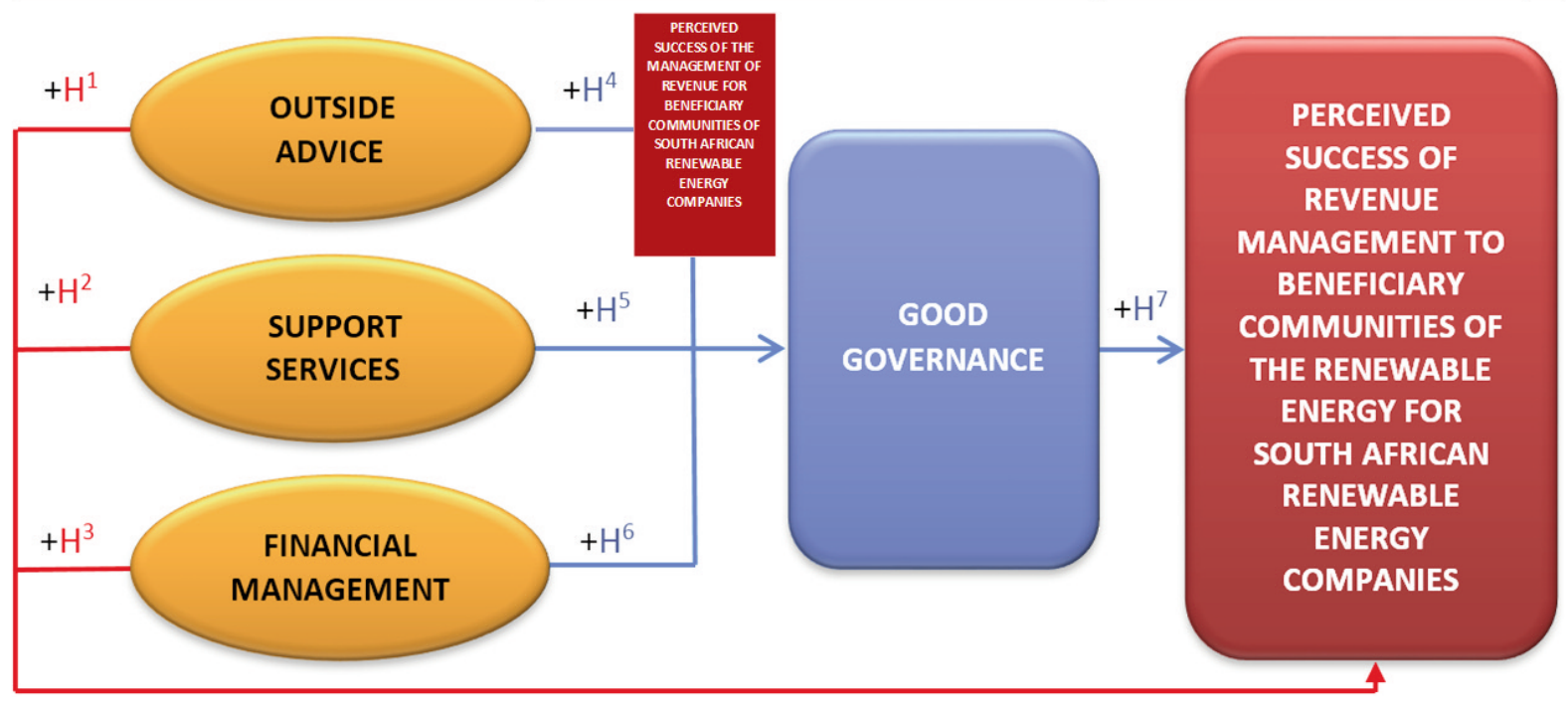

Figure 1: Proposed theoretical model. 
2006). This approach is further endorsed by the Guangcai model approach that promotes multi-sector co-operation between entrepreneurs, governments and non-governmental organisations (Jonker \& De Witte, 2006). The model used by the Holcim Group of companies addresses the preparation, implementation and evaluation of local stakeholder engagement strategies; it details, step by step, the cyclical process of engaging with stakeholders, and each step contains basic principles, tools and mechanisms that enable practitioners to engage with stakeholders, covering a diverse spectrum of cultures, languages, and aspirations (Jonker \& De Witte, 2006). The stakeholder theory, which underpins multi-sector participation, argues that there are other parties involved, including communities, governmental bodies, political groups and trade unions amongst others. The theory attempts to establish which groups are stakeholders in a business and which, therefore, require management attention (Stakeholder Theory, 2006). The term 'stakeholder' indicates a subjective perspective and, therefore, the definition of a stakeholder can be narrow or broad in scope. At a minimum, stakeholders are those groups from whom the organisation has voluntarily accepted benefits, and to whom the organisation has therefore incurred obligations of fairness (Farrington, 2009). A common way of differentiating between the kinds of stakeholders is to consider groups of people who have classifiable relationships with the organisation (Fontaine, 2006) such as customers, employees, local communities, suppliers and distributors, and shareholders.

In addition, the following groups and individuals are considered in the relevant literature to be stakeholders (Friedman, 2006):

- the media;

- the public in general

- business partners;

- future generations;

- past generations (founders of organisations);

- academics;
- competitors;

- NGOs or activists - considered individually as stakeholder representatives;

- stakeholder representatives such as trade unions or trade associations of suppliers or distributors;

- financiers other than stockholders (debt holders, bondholders, creditors);

- competitors; and

- governments, regulators, and policymakers.

It is important to gain a deeper understanding of the importance of stakeholders, who they are, and the role they play in the management of revenue for beneficiary communities. An awareness of possibly raised expectations is crucial when engaging with stakeholders and potential beneficiaries (Wlokas et al., 2012). For the purpose of this study, the term 'stakeholder' includes all parties directly or indirectly associated with or influencing multi-sector participation in the management of revenue for beneficiary communities and would, therefore, require a strategic management approach. Based on a literature review, Table 1 shows the hypotheses considered.

\section{Research objectives}

The research problem was that socio-economic and enterprise development, as one of the main benefits to be derived from the renewable energy sector, is not being achieved, owing to ineffective management of revenue for beneficiary communities of renewable energy companies in RSA. In order to address the problem, the factors that influence the success of revenue management solutions for the renewable energy sector in RSA were investigated and a theoretical business process model was developed for the perceived success of the management of revenue for the beneficiary communities of South African renewable energy companies. Empirical research was conducted to test the proposed process model, comprising various statistical benchmarks of critical cross-field skills, concepts,

Table 1: Hypothesis for Sub-model A.

\begin{tabular}{ll}
\hline Hypothesis & Definition \\
\hline $\mathrm{H}^{1}$ & $\begin{array}{l}\text { There is a positive relationship between the use of specialist outside advice and the perceived success of the } \\
\text { management of revenue for beneficiary communities of South African renewable energy companies. }\end{array}$ \\
$\mathrm{H}^{2}$ & $\begin{array}{l}\text { There is a positive relationship between the use of support services and the perceived success of the } \\
\text { management of revenue for beneficiary communities of South African renewable energy companies. }\end{array}$ \\
$\mathrm{H}^{3}$ & $\begin{array}{l}\text { There is a positive relationship between the use of strategic financial management measures and the } \\
\text { perceived success of the management of revenue for beneficiary communities of South African renewable } \\
\text { energy companies. }\end{array}$ \\
$\mathrm{H}^{4}$ & $\begin{array}{l}\text { There is a positive relationship between the use of specialist outside advice and good governance. } \\
\mathrm{H}^{5}\end{array}$ \\
$\mathrm{H}^{6}$ & $\begin{array}{l}\text { There is a positive relationship between the use of support services and good governance. } \\
\text { There is a positive relationship between the use of strategic financial management measures and good } \\
\mathrm{H}^{7}\end{array}$ \\
& $\begin{array}{l}\text { governance. } \\
\text { There is a positive relationship between good governance structures and the perceived success of revenue }\end{array}$ \\
\end{tabular}


and frameworks. The purpose of this research was to identify the organisational and social variables that will enhance multi-sector participation and promote a model for successful management of revenue for the beneficiary communities of South African renewable energy companies.

The primary objective of this study was to develop a successful revenue management model for beneficiary communities in the renewable energy sector in South Africa. As a result of the split of the original model, the primary objective translated into three sub models, namely: multi-sector participation, transformational change, and sustainable initiatives. The multi-sector participation sub-model provides empirical evidence for the collaboration and partnering of stakeholders, enterprises, and consultants in the renewable energy sector towards a pro-active, effective, and relevant decision-making process to achieve success in revenue management for the beneficiary communities. To address the primary objective a number of secondary objectives were formulated, through the development of a conceptual model consisting of identified variables based on a comprehensive survey of the related literature. By constructing a path diagram between the dependent variable and subsequent independent and intervening variables, appropriate hypotheses were developed. An electronic survey was used to collect primary data from an identified, international population of project management practitioners. These data were empirically analysed using structural equation modelling.

\section{Multi-sector related factors that influence the perceived success of revenue management}

According to the literature (Hohnen, 2012; Krick et al, 2005; Adendorf, 2004; Cavaye, 2010; Hill, 2008), the factors related to multi-sector participation that directly influence the perceived success of the management of revenue for beneficiary communities in this study were outside advice, support services, and financial management. Two variables - outside advice and support services (defined separately below) - did, however, load together to form a factor labelled distinctive benefits. The influence of good governance as an intervening variable was also considered.

\section{Research methodology}

In order to test and develop the theoretical model, a positivistic research paradigm was applied to this research study. The positivistic paradigm is also known as the quantitative, objectivist, scientific, experimentalist or traditionalist research paradigm (Collis \& Hussey, 2003). Convenience snowball or non-probability sampling, rather than pure random or probability sampling was used in this research study because the sample populations could not be readily identified using probability sampling (File \& Prince, 1996). Snowball sampling is appropriate when the members of a special population are difficult to locate (Babbie \& Mouton, 2001). A selfadministered questionnaire is commonly used in positivistic research paradigm (Collis \& Hussey, 2003) and, accordingly, one was developed to source the primary data. Adjustments were made to the measuring instrument after a preliminary evaluation and structured questionnaires were distributed to respondents identified by means of the snowball sampling technique. The return of 219 fully completed questionnaires, which were used for the statistical analysis of the data, indicated the achievement of the fourth secondary objective. A 7-point Likert-type interval scale, ranging from 1 (strongly disagree) to 7 (strongly agree), was used and respondents were requested to indicate the extent of their agreement or disagreement with regard to each statement. The questionnaires were collated online using an Excel-based spread sheet and thereafter downloaded by the researcher for analysis.

To confirm the reliability of the instrument used, the Cronbach's alpha coefficient for each factor was calculated separately. Nine factors were identified during the exploratory factor analysis. Cronbach's alpha values of more than 0.70 were recorded for eight of the nine factors. The Cronbach's alpha coefficient for the remaining factor was higher than the acceptable level of 0.6. The structural equation modelling was the used to test the significance of the causal relationships hypothesised between the variables that influence good governance. The linear structural relations (LISREL) software application (v 8.8) was used to test the relationships among the factors that influence the perceived success of the management of revenue for beneficiary communities. The significant relationships identified in the study and the recommendations about how these determinants can be presented to ensure successful management of revenue for beneficiary communities are discussed in the following section.

\section{Operationalisation of the variables}

Each factor under investigation was operationalised by means of items in the measuring instrument.

\subsection{Independent variable: Outside advice}

For the purpose of this research study, outside advice refers to specialist consultants and experts in the field of renewable energy and revenue management who can add value to the process of revenue management and ensure sustainable and transformational socio-economic development in the beneficiary communities. This would include the streamlining of legal processes, baseline assessments of beneficiary communities, financial management, strategic planning and change management, socioeconomic development and enterprise develop- 
ment project management, multi-stakeholder management and monitoring, and evaluation and reporting procedures all of which would grow and develop beneficiary communities and increase economic growth in RSA.

\subsection{Independent variable: Support services}

Support services refers here to the level of assistance required by renewable energy companies that will enable them to improve their management of revenue for beneficiary communities, which goes beyond the capabilities of the companies and their immediate service providers, including economic development specialists, training, project and stakeholder management, in order to promote successful socio-economic growth in the communities.

\subsection{Independent variable: Financial management}

Financial management refers here to the financial systems and processes employed to ensure sound financial management in renewable energy companies, including the management of revenue for beneficiary communities. Factors such as financial planning and budgeting, financial controls, value management, governance and accountability contribute to the success of management revenue for beneficiary communities.

\subsection{Intervening variable: Good governance} Good governance refers here to the influence of good governance practices and their relationship with the identified variables and the perceived success of the management of revenue for beneficiary communities in RSA. This includes infrastructure, processes, policies, systems and procedures for good governance.

\subsection{Dependent variable: Perceived success of the management of revenue for beneficiary communities.}

The perceived success of the management of revenue for beneficiary communities is defined here as the degree to which the proposed revenue management model resulted in an increase in the quality and sustainability of benefits to beneficiary communities in the short, medium and long terms, thus resulting in transformational socio-economic development that will add to the overall economic development of the country and the reduction of poverty and better job creation.

\section{Structural equation modelling}

After the reliability and discriminant validity of all the variables remaining in the empirical model had been confirmed, the statistical technique, structural equation modelling (SEM), was used to test the series of relationships of the revised model and to ensure the reliability and validity of the findings.
The SEM consists of selecting the input matrix type and estimating the proposed model. The covariance matrix is then used as its input data. The focus of structural equation analysis is not on individual observations, but on the pattern of relationships across respondents (Hair et al., 2010). The measurement model then specifies which manifest variables (indicators), correspond with each latent construct. Structural coefficients are then estimated for the relationships between the latent variables (Hair et al., 2010). Version 8.54 of the LISREL program (Jöreskog and Sörbom, 2003,) was used for the structural equation modelling assessment. The data in the present study shows evidence of non-normality as opposed to the more commonly used maximum likelihood method for estimating the parameters in SEM, therefore an alternative analytical procedure is used, namely, robust maximum likelihood. Robust maximum likelihood compensates for non-normality of the data (Hoogland \& Boomsma 1998; Satorra \& Bentler 1994).

\section{Empirical results of sub-model A: Multi- sector participation}

For sub-model A, labelled Multi-sector participation, the principal axis factoring estimation method with an oblique rotation (Oblimin with Kaiser Normalisation) was specified as the extraction and rotation method. In order to assess the factoranalysability of the data, the IBM software programme SPSS 23 includes Bartlett's Test of Sphericity and Kaiser-Meyer-Olkin (KMO), measure of sampling adequacy. The closer the $\mathrm{KMO}$ is to 1 , the more factor-analysable the data. Bartlett's test of sphericity returned a $\mathrm{KMO}$ value of 0.91 ( $\mathrm{p}<$ $0.00)$, indicating that the data were factoranalysable. In sub-model A, items expected to measure the factors of outside advice, financial management, strategic partnerships, support services and good governance were assessed for discriminant validity by means of exploratory factor analysis. Initially the number of factors to be extracted was not specified, but the eigenvalues suggested a total of five factors to be used as the independent variables in sub-model A. The final solution was reached through an iterative process of deleting items that did not demonstrate sufficient discriminant validity (low loading and cross-loading), and re-running the exploratory factor analysis until all the remaining items loaded to a significant extent ( $p$ $\geq 0.4$ ), with no cross-loadings (i.e. loaded on only one factor). The most interpretable factor structure is presented in Table 2. All items with loadings < 0.4 were deleted. The independent variables were analysed first and the following results were obtained.

Table 2 shows that a total of 17 items (four independent variables and one intervening variable), were grouped into five factors, which explain 
Table 2: Rotated factor loadings: sub-model A (Rotation converged in 8 iterations).

\begin{tabular}{lccccc}
\hline Variable & $\begin{array}{c}\text { Factor } 1 \\
\text { Good governance }\end{array}$ & $\begin{array}{c}\text { Factor } 2 \\
\text { Distinctive benefits }\end{array}$ & $\begin{array}{c}\text { Factor } 3 \\
\text { Support services }\end{array}$ & $\begin{array}{c}\text { Factor } 4 \\
\text { Outside advice }\end{array}$ & $\begin{array}{c}\text { Factor } 5 \\
\text { Financial management }\end{array}$ \\
\hline GG3 & $0.955^{*}$ & 0.049 & 0.028 & -0.078 & -0.067 \\
FM5 & $0.823^{*}$ & -0.070 & -0.016 & 0.035 & 0.026 \\
GG2 & $0.809^{*}$ & -0.005 & -0.004 & 0.109 & -0.080 \\
GG4 & $0.723^{*}$ & -0.012 & -0.033 & 0.087 & 0.038 \\
GG5 & $0.663^{*}$ & 0.087 & 0.001 & -0.079 & 0.127 \\
FM3 & $0.520^{*}$ & 0.077 & -0.051 & -0.051 & 0.269 \\
GG1 & $0.417^{*}$ & -0.109 & -0.052 & 0.151 & 0.235 \\
OA1 & 0.038 & $0.938^{*}$ & 0.116 & 0.005 & -0.013 \\
OA3 & -0.004 & $0.591^{*}$ & -0.179 & 0.207 & -0.015 \\
SS1 & -0.008 & $0.554^{*}$ & -0.220 & -0.041 & 0.112 \\
SS5 & -0.023 & -0.005 & $0.947^{*}$ & 0.011 & -0.041 \\
SS4 & 0.050 & 0.046 & $0.638^{*}$ & -0.020 & 0.072 \\
OA2 & 0.016 & 0.026 & 0.094 & $0.693^{*}$ & 0.113 \\
OA4 & 0.101 & 0.025 & -0.152 & $0.457^{*}$ & 0.062 \\
OA5 & 0.073 & 0.034 & -0.258 & $0.430^{*}$ & -0.201 \\
FM1 & 0.048 & 0.033 & 0.024 & 0.108 & $0.738^{*}$ \\
FM2 & 0.102 & 0.027 & -0.072 & 0.028 & $0.696^{*}$ \\
Eigenvalue: & 6.969 & 2.632 & 1.037 & 0.875 & 0.772 \\
\hline
\end{tabular}

* = significant loadings ( $\mathrm{p} \geq 0.4$ ), GG3 = Good governance, FM5 = Financial management, OA = Outside advice, SS = Support services

$72.27 \%$ of the variance in the data. The same procedure was followed for the factor analyses of the intervening variable.

\subsection{Factor 1: Intervening variable - good governance}

All five of the items that were expected to measure the construct of good governance loaded together on one factor as expected. Good governance explains the $41.00 \%$ of the variance in the data and an eigenvalue of 6.97 was reported in Table 2. Two items expected to measure the factor of financial management also loaded onto the factor of good governance. All factor loadings exceeded 0.4 and were thus regarded as significant. Sufficient evidence of discriminant validity of the construct was thus provided. The Cronbach's alpha coefficient of 0.91 for good governance suggests that the instrument used to measure this construct is reliable. Despite the inclusion of two of the items loading onto the factor of good governance, the operationalisation of good governance as described remained unchanged. For the purposes of this study, good governance refers to the influence of good governance practices and their relationship with the identified variables and the perceived success of the management of revenue for beneficiary communities in RSA. These practices include infrastructure, processes, policies, systems and procedures for good governance.

\subsection{Factor 2: Distinctive benefits}

Only two of the five items (OA1 and OA3) expected to measure the construct of outside advice loaded together on Factor 2. Three items (OA2, OA4 and OA5) loaded onto Factor 4 which also measures outside advice. The inclusion of one of the items (SS1), loading onto the factor of outside advice, resulted in this construct being renamed: distinctive benefits, and redefined on the basis of the results of the factor analysis. Distinctive benefits explain $15.49 \%$ of the variance in the data and an eigenvalue of 2.63 was reported in Table 2. All factor loadings exceeded 0.4 and were thus regarded as significant. Sufficient evidence of discriminant validity of the construct was thus provided. The Cronbach's alpha coefficient of 0.82 for distinctive benefits suggests that the instrument used to measure this construct is reliable. The operationalisation of distinctive benefits for the purpose of this study refers to the use of the services of highly specialised, outside consultants and experts in the field of community development that provide unique and communityspecific benefits for the beneficiary communities, for example: language, culture and baseline knowledge of the specific area's needs and risks.

\subsection{Factor 3: Support services}

Only two of the five items used to measure the construct of support services loaded together on this factor. The item SS3 did not load on any of the factors and, therefore, was deleted and not used in the 
subsequent analysis. Support services explain $6.10 \%$ of the variance in the data and an eigenvalue of 1.04 was reported in Table 2. All factor loadings exceeded 0.4 and were thus regarded as significant. Sufficient evidence of discriminant validity of the construct was thus provided. The Cronbach's alpha coefficient of 0.78 for support services suggests that the instrument used to measure this construct is reliable.

\subsection{Factor 4: Outside advice}

Three of the five items that were expected to measure the construct of outside advice loaded together on one factor. Outside advice explains the $5.15 \%$ of the variance in the data and an eigenvalue of 0.88 was reported in Table 2. All factor loadings exceeded 0.4 and were thus regarded as significant. Sufficient evidence of discriminant validity of the construct was thus provided. The Cronbach's alpha coefficient of 0.66 for outside advice suggests that the instrument used to measure this construct is reliable. With the inclusion of three out of five of the items loading on to the factor of outside advice, the operationalisation of outside advice, as described, remained unchanged (Section 7.1). Factor 5: Financial management

Two of the five items that were expected to measure the construct of financial management loaded together on one factor. Financial management explains $4.54 \%$ of the variance in the data and an eigenvalue of 0.77 was reported in Table 2 . All factor loadings exceeded 0.4 and were thus regarded as significant. Sufficient evidence of discriminant validity of the construct was thus provided. The Cronbach's alpha coefficient of 0.78 for financial management suggests that the instrument used to measure this construct is reliable. Despite the inclusion of only two of the five items loading on to the factor of financial management, the operationalisation of financial management, as described, remained important (Section 7.2)

\section{Reformulation of the hypotheses and the revised theoretical model}

The first sub-model was constructed by using a path diagram to represent the causal relationships between the antecedent variables of: distinctive benefits, outside advice, support services, financial management and the intervening variable of good governance, and the dependent variable of perceived success of revenue management (Figure 2).

Two variables, namely outside advice and support services, did, however, load together to form a factor labelled distinctive benefits (DISB) and two variables, namely education and infrastructure development, loaded together to form a factor labelled developmental benefits (DEVB). The independent variables of change management and strategic partnerships were removed from the proposed theoretical model because their discriminant validity could not be confirmed by the exploratory factor analysis. After the reliability and discriminant validity of all the variables remaining in the empirical model had been confirmed, the statistical technique of SEM was used to test the series of relationships in the revised model.

\section{Assessment of goodness of fit}

Before the SEM analysis was carried out, an assessment of the multivariate normality of the data was conducted. The following hypotheses were formulated for this purpose:

- $\mathrm{H}_{0}$ : The data are normally distributed.

- $\mathrm{H}_{\mathrm{a}}$ : The data are not normally distributed.

The null hypothesis and the alternative hypothesis as formulated above were evaluated by assessing

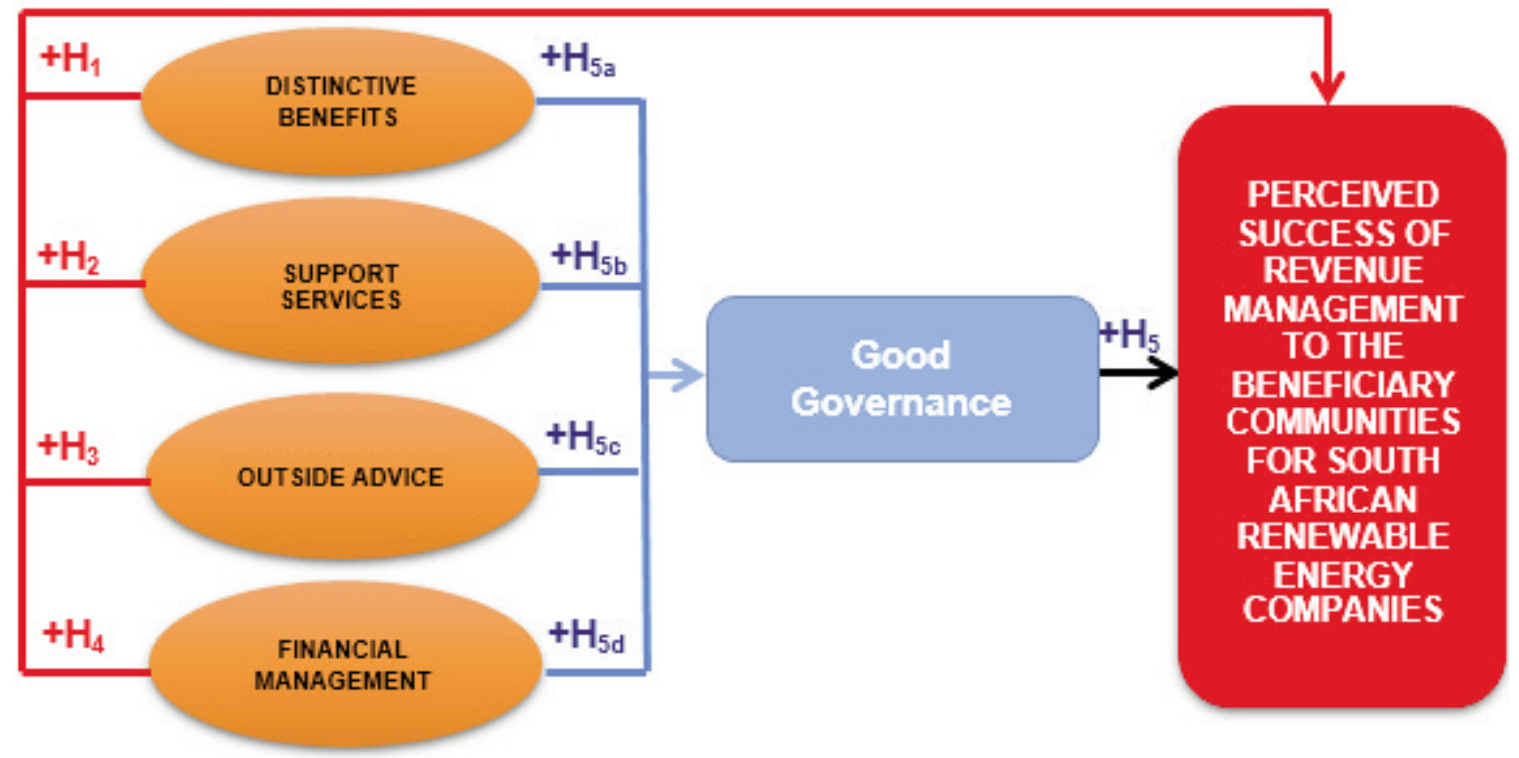

Figure 2: Path diagram of causal relationships: Revised theoretical model (sub-model A). 
Table 3: Reformulated hypotheses.

\begin{tabular}{|c|c|}
\hline $\mathrm{H}^{1}$ & $\begin{array}{l}\text { There is a positive relationship between distinctive benefits and the perceived success of revenue } \\
\text { management. }\end{array}$ \\
\hline $\mathrm{H}^{2}$ & $\begin{array}{l}\text { There is a positive relationship between the implementation of outside advice measures and the perceived } \\
\text { success of revenue management. }\end{array}$ \\
\hline $\mathrm{H}^{3}$ & There is a positive relationship between support services and the perceived success of revenue management. \\
\hline $\mathrm{H}^{4}$ & $\begin{array}{l}\text { There is a positive relationship between the importance of financial management and the perceived success } \\
\text { of revenue management. }\end{array}$ \\
\hline $\mathrm{H}^{5}$ & $\begin{array}{l}\text { There is a positive relationship between the use of good governance and the perceived success of revenue } \\
\text { management. }\end{array}$ \\
\hline $\mathrm{H}^{5 \mathrm{a}}$ & There is a positive relationship between distinctive benefits and good governance. \\
\hline $\mathrm{H}^{5 \mathrm{~b}}$ & There is a positive relationship between the implementation of outside advice and good governance. \\
\hline $\mathrm{H}^{5 \mathrm{c}}$ & There is a positive relationship between support services and good governance. \\
\hline $\mathrm{H}^{5 \mathrm{~d}}$ & There is a positive relationship between financial management and good governance. \\
\hline
\end{tabular}

Table 4: Fit indices for the measurement and structural sub-model A - intervening variable.

\begin{tabular}{lcc}
\hline & Relationship between the independent & and intervening variables (good governance) \\
\hline Item & Measurement model & Structural model \\
\hline Sample size & 219 & 219 \\
\hline Degrees of freedom & 215 & 94 \\
\hline Satorra- Bentler scaled chi-square & $361.691(\mathrm{p}=0.00)$ & $231.120(\mathrm{p}=0.00)$ \\
\hline / degrees of freedom & 1.68 & 2.46 \\
\hline Root mean square error of approximation (RMSEA) & 0.0559 & 0.0818 \\
\hline 90\% confidence interval for RMSEA & $(0.0450 ; 0.932)$ & $(0.0685 ; 0.0952)$ \\
\hline Expected cross-validation index (ECVI) & 2.219 & 1.446 \\
\hline
\end{tabular}

the skewness and the kurtosis of the data, while the chi-square $(\chi 2)$ value was used to determine the relevant $\mathrm{p}$-value. The results of the test of multivariate normality for the relationship between the independent and intervening variables are presented as follows.

\section{The measurement and structural model - (intervening variable of good governance)}

Table 4 shows the fit indices for sub-model A which assess the relationship between the four independent variables (distinctive benefits, outside advice, support services and financial management), and good governance.

\subsection{Measurement model}

The fit indices for the measurement model depicted in Figure 3 are reported in Table 3. The Satorra Bentler divided by the degrees of freedom is 1.68 , which is lower than the acceptable value of 2 and is an indicator of a good fit. The RMSEA $0.0559<$ 0.06 indicates a relatively good fit $(\mathrm{Hu} \&$ Bentler, 1991), while the upper limit of the $90 \%$ confidence interval for RMSEA (0.0932) is in the range of 0080.10 which is considered a mediocre or inadequate fit (MacCullum, Browne \& Sugawara, 1996; Roberts \& Ilardi, 1982). However, according to the comparative fit index (CFI) of 0.961 , the fit of this model is poor but marginally so (Roberts \& Ilardi, 1982).

\subsection{Structural model}

The Satorra Bentler $\chi 2$ divided by the degrees of freedom ratio is 2.46 , which is slightly higher than the acceptable value of 2 . The value $<2$ indicates a good fit. The RMSEA (0.0818), which is marginally greater than 0.08, indicates a poor fit (MacCullum, Browne \& Sugawara, 1996), while the upper limit of the $90 \%$ confidence interval for RMSEA (0.0952) is in the range of 008-0.10 which is considered a mediocre or inadequate fit according to (MacCullum, Browne \& Sugawara, 1996; Roberts \& Ilardi, 1982). However, according to the CFI of 0.961 , the fit of this model is poor but marginally so (Roberts \& Ilardi, 1982).

\subsection{The measurement and structural sub- model A - (dependent variable of perceived success)}

The following table represents the fit indices for submodel A which assess the relationship between the independent variables (distinctive benefits, outside advice, support services and financial management) and the perceived success of revenue management (dependent variable).

\subsection{Measurement model}

The Satorra Bentler $\chi 2$ divided by the degrees of freedom ratio is 2.46 , which is slightly higher than the acceptable value of 2 . The value $<2$ indicates a good fit. The RMSEA (0.0818), which is marginally 
Table 5: Fit indices for the measurement and structural sub-model A (dependent variable).

\begin{tabular}{lcc}
\hline Relationship between the independent and dependent variables (perceived success) & \\
\hline Item & Measurement model & Structural model \\
\hline Sample size & 219 & 219 \\
\hline Degrees of freedom & 94 & 129 \\
\hline Satorra-Bentler scaled chi-square $\chi 2$ & $231.120(\mathrm{p}=0.00)$ & $202.449(\mathrm{p}=0.00)$ \\
\hline SB $\chi 2$ / degrees of freedom & 2.46 & 1.57 \\
\hline RMSEA & 0.0818 & 0.0511 \\
\hline $90 \%$ confidence interval for RMSEA & $(0.0685 ; 0.0952)$ & $(0.0371 ; 0.0643)$ \\
\hline ECVI & 1.446 & 1.314 \\
\hline
\end{tabular}

greater than 0.08, indicates a poor fit (MacCullum, Browne \& Sugawara, 1996), while the upper limit of the $90 \%$ confidence interval for RMSEA (0.0952) is in the range of $008-0.10$, which is considered a mediocre or inadequate fit (MacCullum, Browne \& Sugawara, 1996; Roberts \& Ilardi, 1982). However, according to the CFI of 0.961 , the fit of this model is poor but marginally so (Roberts \& Ilardi, 1982).

\subsection{Structural model}

The goodness-of-fit indices for the structural model depicted in Figure 3 are reported in Table 5. The Satorra Bentler $\chi 2$ divided by the degrees of freedom is 1.57 which is considerably lower than 2 . Values lower than 2 are considered to be a close fit. The RMSEA of $(0.0530)<0.06$ is regarded as a close fit (Hu \& Bentler, 1991), while the upper limit of the $90 \%$ confidence interval for RMSEA 0.0643 $<0.08$ is a good fit and considered to be below the upper limit of the confidence level. These fit indices all provide evidence of a model with a close fit. Consequently, the null hypothesis, that the data fits the model perfectly, must be rejected. However, although the data does not fit the model perfectly, it can be described as having a close fit.

\subsection{Structural and measurement model}

Figure 3 shows the structural estimation for submodel A.

\section{Empirical results}

In the sections below, the various steps of SEM are applied to sub-model A as depicted in Figure 3 in order to evaluate whether the various hypotheses associated with this sub-model should be accepted.

\subsection{Distinctive benefits and the perceived success of revenue management}

$\mathrm{H}_{1}$ - There is a positive relationship between distinctive benefits and the perceived success of revenue management.

The empirical results of this study showed that distinctive benefits do not have a significant influence on the perceived success of revenue management (point estimate $=-0.22, \mathrm{p}>0.00, \mathrm{t}=1.32$ ) Hypothesis 1 must thus be rejected.

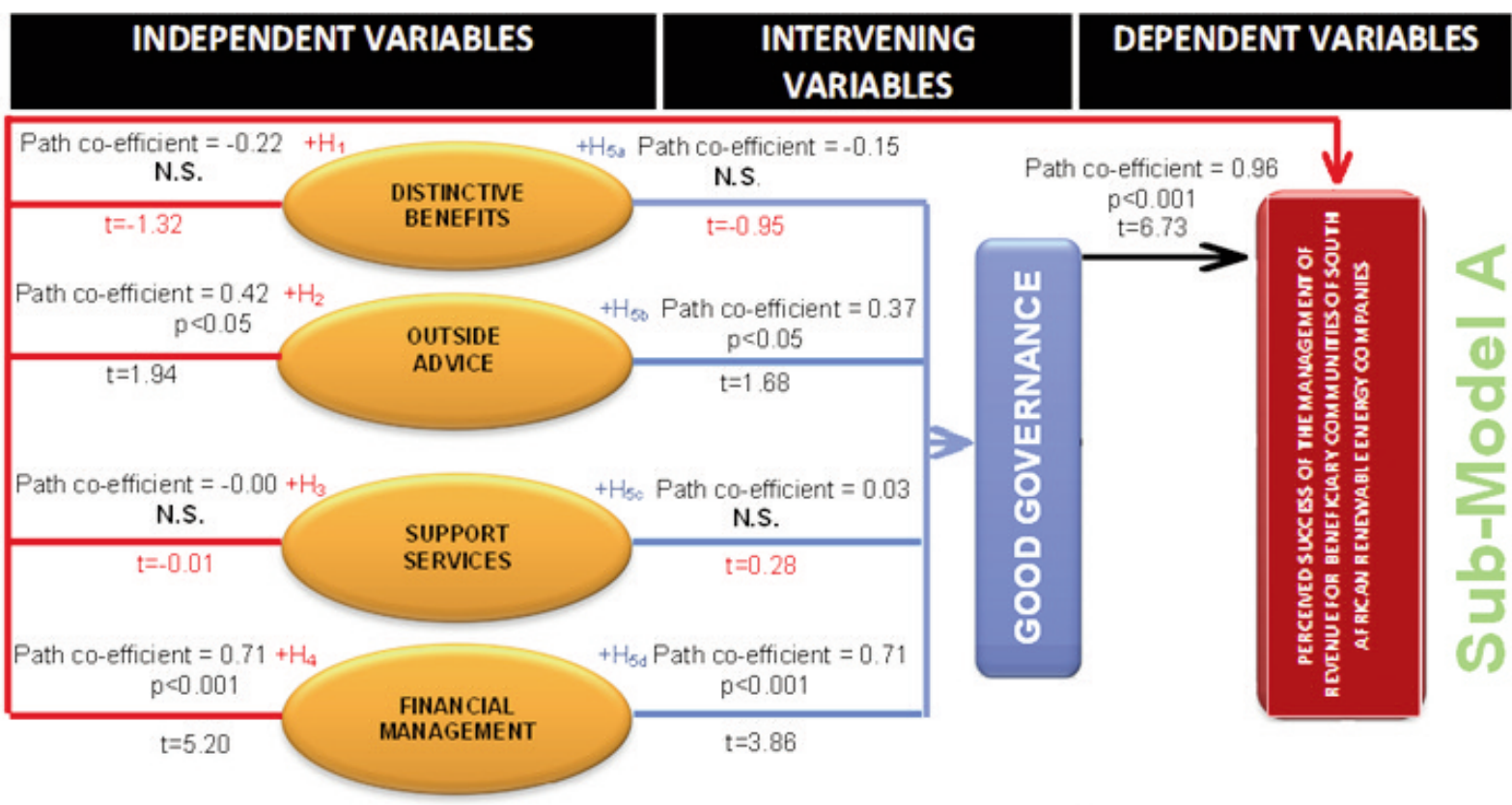

Figure 3: Structural estimation for sub-model A (including t-values), where N.S. = non-significant. 
12.2 Outside advice and the perceived success of revenue management

$\mathrm{H}_{2}$ - There is a positive relationship between the implementation of outside advice measures and the perceived success of revenue management.

Various sources, both practitioner oriented and academic (Hohnen, 2012; Krick et al, 2005), have suggested that the implementation of outside advice can improve the perceived success of revenue management and it is against this background that $\mathrm{H}_{2}$ was assessed. It can be seen from Figure 3 that the implementation of outside advice is positively related to the perceived success of revenue management (point estimate $=0.42, \mathrm{p}<0.05$, $=1.94$ ) with a $5 \%$ level of significance. Hypothesis 2 is thus accepted. Hypothesis 2 suggests that when renewable energy companies make use of outside advice, it will have a favourable effect on revenue management processes. This empirical result is consistent with prior research (Jonker \& De Witte, 2006; Engelbrecht, 2009; Durant, 2013; South African Department of Social Development, 2009).

\subsection{Support services and the perceived success of revenue management}

$\mathrm{H}_{3}$ - There is a positive relationship between support services and the perceived success of revenue management.

The empirical results of this study revealed that support services do not have a significant influence on the perceived success of revenue management (point estimate $=-0.00, \mathrm{p}>0.00, \mathrm{t}=-0.01$ ). Hypothesis 3 must thus be rejected.

\subsection{Financial management and the} perceived success of revenue management $\mathrm{H}_{4}$ - There is a positive relationship between the importance of financial management and the perceived success of revenue management.
Various sources, including academic and industry experts, suggest that the use of financial management systems will enhance the perceived success of revenue management. It is against this background that $\mathrm{H}_{4}$ was assessed. Figure 3 shows that the implementation of sound financial management practices is positively related to the perceived success of the management of revenue for beneficiary communities (point estimate $=0.71, \mathrm{p}<0.001, \mathrm{t}=$ 5.20). Hypothesis 4 suggests that, when renewable energy companies implement sound financial management practices, it will improve their management of beneficiary revenue significantly. This empirical result is supported by prior research (D'Amato, Henderson \& Florence, 2009; Wong \& Guggenheim, 2005; Watkins, Meiers \& Visser, 2012; World Bank, 2012).

\subsection{Good governance and perceived success of revenue management}

$\mathrm{H}_{5}$ - There is a positive relationship between good governance and the perceived success of revenue management.

Several sources, both academic and practitioner oriented, have suggested that the implementation of good governance practices can enhance the perceived success of revenue management (Johnston, 2009; Biery, 2014). Figure 3 confirms that the use of good governance practices is positively related to the perceived success of the management of revenue for beneficiary communities (point estimate = $0.96, p<0.001, t=6.37$ ) with a $0.1 \%$ level of significance. Hypothesis 5 is thus accepted. Hypothesis 5 suggests that, when renewable energy companies introduce good governance measures in the management of beneficiary revenues, the outcomes of community development projects will be improved significantly. Researchers and writers such as Jonker and De Witte (2006), Walker and

Table 6: Summary of all the sub-model A hypotheses.

\begin{tabular}{llc}
\hline Hypotheses & Definition & Status \\
\hline $\mathrm{H}_{1}$ & $\begin{array}{l}\text { There is a positive relationship between distinctive benefits and the perceived success of } \\
\text { revenue management. }\end{array}$ & Rejected \\
\hline $\mathrm{H}_{2}$ & $\begin{array}{l}\text { There is a positive relationship between the implementation of outside advice measures } \\
\text { and the perceived success of revenue management. }\end{array}$ & Supported \\
\hline $\mathrm{H}_{3}$ & $\begin{array}{l}\text { There is a positive relationship between support services and the perceived success of } \\
\text { revenue management. }\end{array}$ & Rejected \\
\hline $\mathrm{H}_{4}$ & $\begin{array}{l}\text { There is a positive relationship between importance of financial management and the } \\
\text { perceived success of revenue management. }\end{array}$ & Supported \\
\hline $\mathrm{H}_{5}$ & $\begin{array}{l}\text { There is a positive relationship between the use of good governance and the perceived } \\
\text { success of revenue management. }\end{array}$ & Supported \\
\hline $\mathrm{H}_{5 \mathrm{a}}$ & There is a positive relationship between distinctive benefits and good governance. & Rejected \\
\hline $\mathrm{H}_{5 \mathrm{~b}}$ & $\begin{array}{l}\text { There is a positive relationship between the implementation of outside advice and good } \\
\text { governance. }\end{array}$ & Supported \\
\hline $\mathrm{H}_{5 \mathrm{c}}$ & There is a positive relationship between support services and good governance. & Rejected \\
\hline $\mathrm{H}_{5 \mathrm{~d}}$ & There is a positive relationship between financial management and good governance. & Supported \\
\hline
\end{tabular}


Mokoena (2011), Engelbrecht (2009), Erasmus (2014), Johnston (2009), Boyce et al. (2007) and Rossouw (2012) support this empirical finding.

\section{Summary and recommendations}

The independent variables associated with submodel of multi-sector participation, including distinctive benefits, support services, outside advice and financial management, and the intervening variable of good governance, allude to multi-sector participation in revenue management for beneficiary communities. 'Multi-sector' refers to the involvement of government, the private sector and civil society. 'Participation' refers to taking advantage of knowledge and skills, accessing expertise, forming partnerships and accessing resources. The spirit of ubuntu, expressed as 'I am because of others' must be deliberately and actively embraced and put into practice. It must be noted that financial management and good governance are important components of the sub-model and should be treated as such. The link between corporate social responsibility and revenue management as discussed confirms the importance of multi-sector participation. Multisector participants should include the following:

- local government - Integrated Development Plan;

- provincial government - Provincial Strategic Plan;

- national government - National Development Plan;

- private sector - IPPs, service providers, consultants etc;

- community-based organisations - NPOs, community forums etc; and

- academic institutions - universities, technical colleges etc.

The role of the intervening variable, good governance, must form an integral part of this submodel to ensure that multi-sector participation includes and assists the beneficiary community at all times and in every situation. Good governance principles can be included in activities such as:

- the appointment of industry experts and service providers;
- the formation of multi-sector partnerships or collaborates;

- the management of finance and financial transactions;

- the monitoring, evaluation and reporting of all activities; and

- the inclusion of policies and procedures in all management processes.

Co-ordinated multi-sector participation through providing support services, outside advice and financial management can contribute meaningfully towards successful development in beneficiary communities. Table 7 gives keys steps to consider for multi-stakeholder management.

The study provided new insight into revenue management for beneficiary communities in the RSA. With the renewable energy sector being one of the fastest growing sectors in the RSA, and the government being determined to link the location of renewable energy facilities to economic development, this research has given new insight into SED and $\mathrm{ED}$ revenue management and contributes to the body of knowledge concerning revenue management for beneficiary communities. A continuation to this article titled, 'Sub-model B - The success of transformational change on the management of revenue for beneficiary communities of South African renewable energy companies", will be written soon. This will be followed by the third and final article in the series titled 'Sub-model C - The success of sustainable initiatives on the management of revenue for beneficiary communities of South African renewable energy companies'. A proposed final article will conclude the study conducted by the author on 'A theoretical model for successful management of revenue for beneficiary communities of renewable energy companies in South Africa'.

\section{References}

Adendorff, C.M. 2004. The development of a cultural family business model of good corporate governance for Greek family businesses in South Africa, Unpublished doctoral thesis, Grahamstown: Rhodes University.

Table 7: Key steps for multi-stakeholder management.

\begin{tabular}{ll}
\hline Key steps & Description \\
\hline $\begin{array}{l}\text { Identify } \\
\text { The drawing up of a database of stakeholders based on formal and informal interaction } \\
\text { with local government, community leadership and community based organisations and } \\
\text { influential others. }\end{array}$ \\
\hline Categorise & Stakeholders are categorised in endemic groups as identified above. \\
\hline Prioritise & Stakeholders are place in levels of importance and influence. \\
\hline Engage & The level, frequency and form of engagement of are based on the prioritisation sphere. \\
\hline Monitor and report & Various internal and contextual monitoring is done and reported on regularly. \\
\hline Evaluate and prioritise & Evaluate the relationship in terms of influence and importance and re-assign prioritisation.
\end{tabular}


Agenor, P. A and Agenor, M. A. 2013. Infrastructure, women's time allocation, and economic development. Journal of Economics/ Zeitschrift fur Nationalokonomie. 113(1): 1-30.

Amansure, R.J. 2016. A theoretical for successful management of revenue for beneficiary communities of renewable energy companies in South Africa. Unpublished doctoral thesis, Nelson Mandela Metropolitan University, Port Elizabeth.

Babbie, E. and Mouton, J. 2001. The practice of social research. Cape Town: Oxford University Press.

Boateng, N. A. 2012. Promoting rural enterprise growth and development: Lessons from four projects in subSaharan Africa. Rome: International Fund for Agricultural Development.

Boyce, D. S., Griffith, G. M. and King, J. R. 2007. Best practices in non-profit governance: Dealing with 'voluntary' reforms. Corporate Governance Advisor 15(3): 25-28.

Casey, K., Glennerster, R. and Miguel, E. 2014. Reshaping institutions: Evidence on aid impacts using a pre-analysis plan. The Quarterly Journal of Economics, 127(4): 1755-1812.

Cavaye, J. 2001. Rural Community Development: New Challenges and Enduring Dilemmas. Journal of Regional Analysis and Policy. 31:109-124.

City of Chandler. 2010. Project management methodology step-by-step guide to managing successful projects. Project Management Methodology Guidelines. (1) 9 .

Collis, J. and Hussey, R. 2003. Business research: A practical guide for undergraduate and postgraduate students. $2^{\text {nd }}$ Edition. London: Palgrave Macmillan.

Crowther, D. and Aras, G. 2008. Corporate social responsibility. London: Ventus. Available online at: bookboon.com.

Durant, G. 2013. Audit Committee Resource Guide. Johannesburg: Deloitte \& Touche.

Dutton, W. 2004. Social transformation in an information society: Rethinking access to you and the world. United Nations Educational, Scientific and Cultural Organization, Paris.

Economic Commission for Africa. 2013. Infrastructure development and rural transformation issues. Paper on Infrastructure Development and Rural Transformation. Benin: Economic Commission for Africa.

Engelbrecht, L. 2009. Principles for South Africa. Vol. 1. Parklands, South Africa: Institute of Directors in Southern Africa. Available online at: www.lodsa.co.za.

Farrington, S. M. 2009. Sibling partnerships in South African small and medium-sized family businesses. Unpublished doctoral thesis, Nelson Mandela Metropolitan University, Port Elizabeth.

Fontaine, C., Haarman, A. and Schmid, S. 2006. The stakeholder theory. Stakeholder theory of the MNC. [Online] Available online at: http://www.martonomily.com/sites/default/files/attach/Stakeholders\%20theory.pdf.

Fourie, J. 2006. Some policy proposals for future infrastructure investment in South Africa. Stellenbosch Economic Working Papers. University of Stellenbosch, Stellenbosch.
Friedman, A. L. and Miles, S. 2006. Stakeholders: Theory and practice. New York: Oxford University Press.

Gillespie, S. 2004. Scaling up community-driven development: A synthesis of experience. International Food Policy Research Institute, Washington, D.C.

Glickman, N. 2014. Global study shows clean energy activity surges in developing world - China, Brazil and South Africa show wide diversity of clean energy investment opportunities. Bloomberg New Energy Finance, London.

Hair, J. F., Black, W. C., Babin, J. B., Anderson, R. E. \& Tatham, R. L. 2006. Multivariate data analysis. $6^{\text {th }}$ Edition. Upper Saddle River, New Jersey: Pearson/Prentice Hall.

Halina, W., Wilson, E. and Zarsky, L. 2007. Sustainable development innovation briefs: CSR and developing countries. UN Sustainable Development. United Nations Department of Economic and Social Affairs, New York. (1)8-15.

Hemson, D., Meyer, M. and Kealeboga, M. 2004. Rural development: The provision of basic infrastructure services. Human Sciences Research Council. KwaZulu-Natal.

Hill, A. 2008. Strategic Financial management. Vol. 1. Finance \& Ventus Publishing APS. Available online at: https://slp.somerset.org.uk/sites/slc/ Leadership\%20Library/Strategic\%20Financial\%20M anagement.pdf

Hohnen, P. 2012. Corporate Social Responsibility - An Implementation Guide For Business. J. Potts (ed.). Winnipeg, Manitoba, Canada: International Institute for Sustainable Development.

Hu, L. and Bentler, P. M. 1999. Cut-off criteria for fit indexes in covariance structure analysis:

Conventional criteria versus new alternatives. Structural Equation Modelling Department of Psychology, University of California, Los Angeles6(1): 1-55.

Johnston, M. 2009. Good governance: Rule of law, transparency and accountability. Working Paper. Department of Political Science, Colgate University, New York.

Jonker, J. and De Witte, M. 2006. Management models for corporate social responsibility. New York: Springer.

Kepner, K. \& Wysocki, A. 2012. Financial management: Some important generalizations. University of Florida, Florida, USA.

Krick, T., Forstater, M., Monaghan, P. \& Sillanpää, M. 2005. The practitioner's handbook on stakeholder engagement. Vol. 2 of The stakeholder engagement manual. AccountAbility, United Nations Environment Programme, and Stakeholder Research Associates Canada. Available online at: http://www.unep.fr/shared/publications/pdf/WEBx011 5xPA-SEhandbookEN.pdf.

Lewis, K. \& Ferguson, J, (eds.) A guide to leadership tasks and functions. Greensboro, North Carolina: CCL Press.

MacCallum, R. C., Browne, M. W. and Cai, L. 2006. Testing differences between covariance structure models: Power analysis and null hypothesis. Psychological Methods, 11(1): 19-35. 
doi:10.1037/1082-989X.11.1.19; 10.1037/1082989X.11.1.19.supp.

Mazurkiewicz, P. 2004. Corporate environmental responsibility: Is a common CSR framework possible? World Bank Legal Department. 1-18. Available online at: http://siteresources.worldbank.org/EXTDEVCOMSUSDEVT/Resources/csrframework.pdf.

Nickols, F. 2016. Strategy: Definitions and meanings. Available online at: http://www.nickols.us/ strategy_definitions.pdf.

Nyahuye, D. C. 2012. Corporate social investment. Available online at: http://www.total.co.za/pro/totalgaz-main/totalgaz-csi.html.

Paramasivan, C. and Subramanian, T. 2009. Financial management. New Delhi: New Age International.

Project Management Institute. 2013. A Guide to the project management body of knowledge. $P M B O K$ Guide, Vol. 44. Project Management Institute, Pennsylvania.

Politis, J. D. 2003. The connection between trust and knowledge management: What are its implications for team performance? Journal of Knowledge Management, 7(5): 55-66.

Roberts, M. C., Stephen, S. and Ilardi, S. S. 2003. Handbook of research methods in clinical psychology. Oxford: Blackwell.

Renewable Energy Network for the $21^{\text {st }}$ Century (REN21). 2014. Global status report. UNEP, Paris, France. Available online at: www.ren21.net.

Rossouw, D. 2012. The social and ethics committee handbook - Guidebook for South African companies. Ethics Institute of South Africa. Pretoria, South Africa.

South African Wind Energy Association (SAWEA). 2014. Wind and socio-economic development in SA. CEO Blog. Available online at: http://www. sawea.org.za/ceo-blog/87-wind-socio-economicdevelopment-in-sa.html.

South African Department of Social Development. 2009. Developing good governance practices within the South African NPO Sector: benchmark study. Department of Social Development, Pretoria.

Tang, Y., Kabir, R., Beuschiem, H. van, Madishetti, S., Kibona, D., García-Teruel, P.J., Martínez-Solano, P., Gul, S. et al. 2013. Financial management challenges in small and medium-sized enterprises: A strategic management approach. International Journal of Managerial Finance 5(1): 3875-3885.

Too, E.G. and Weaver, P. 2013. The management of project management: A conceptual framework for project governance. International Journal of Project Management 32(8): 1382-1394.

Van der Walt, G. 2012. Project management: A new service delivery paradigm. Koers - Bulletin for Christian Scholarship, 72(2): 239-260.

Watkins, R. and Meiers, M. W. 2012. A guide to assessing needs: Essential tools for collecting information, making decisions, and achieving development results. Washington DC: World Bank.

Wong, S. and Guggenheim, S. 2005. Community-driven development: Decentralization's accountability chal- lenge. World Bank. Washington, D.C.

World Bank. 2007. Enhancing agricultural innovation. World Bank, Washington, D.C.

World Bank. 2012. Mining community development agreements. World Bank, Washington, D.C. 